\title{
Sri Lankan Travel and Tourism Industry: Recent Trends and Future Outlook towards Real Estate Development
}

\author{
Lasika Madhawa Munasinghe ${ }^{1}$ \\ Department of Estate Management and \\ Valuation \\ University of Sri Jayewardenepura \\ Nugegoda, Sri Lanka \\ lasika@sjp.ac.lk
}

\author{
Terans Gunawardhana \\ Department of Estate Management and \\ Valuation \\ University of Sri Jayewardenepura \\ Nugegoda, Sri Lanka \\ terans@sjp.ac.lk
}

\author{
R. G. Ariyawansa \\ Department of Estate Management and \\ Valuation \\ University of Sri Jayewardenepura \\ Nugegoda, Sri Lanka \\ ariyaw71@sjp.ac.lk
}

\begin{abstract}
Tourism is considered as an important economic activity around the world due to its direct economic impact as well as it is significant indirect and induced impacts. Granting to the World Travel and Tourism Council, Travel and Tourism Industry is one of the world's most significant economic sectors accounting for $10.4 \%$ of global GDP and 313 million jobs, or 9.9\% of total employment, in 2017. The direct and indirect impact of the industry on real estate development in the world is tremendous in terms of accommodation, catering to food and beverages, leisure, pleasure and relaxation. In Sri Lanka, tourism is the third-largest export earner in the economy, and during the past five years, there has been an unprecedented growth in the industry. However, tourism in Sri Lanka has much more untapped potential; thereby, the sector is poised to generate a range of growth and investment opportunities. However, it is only through the right policies and investment decisions; Sri Lanka can leverage the economic prospects of the Travel and Tourism Industry. This study analyses the importance of the Travel and Tourism Industry in terms of real estate development. It reviews significant trends that are shaping the growth and development of the Travel and Tourism Industry in Sri Lanka and aim to produce useful inputs for policy implications. The analysis is based on modified Tourism Satellite Account: Recommended Methodological Framework 2008 published by World Travel and Tourism Council, and carried out analysing both academic and non-academic publications, including published journal articles, annual and quarterly reports published by United Nations' World Tourism Organization, World Travel and Tourism Council, World Economic Forum and Sri Lanka Tourism Development Authority and through the raw data obtained by World Travel and Tourism Council for Sri Lanka. As per the analysis, the future outlook is bright for the tourism sector in Sri Lanka, and the country is expected to maintain a high rate of growth well into the next decade.
\end{abstract}

Keywords - Tourism Trends, Real Estate Development, Travel and Tourism Industry, Sri Lanka

\section{INTRODUCTION}

Tourism is an economic and social phenomenon which has experienced continuous growth and deepening diversification over the decades. At present, for many regions and countries, tourism has become an important, even vital source of income and is one of the fastest-growing economic sectors in the world. Its significance was recognized in the Manila Declaration on World Tourism in 1980 as "an activity essential to the life of nations because of its direct effects on the social, cultural, educational, and economic sectors of national societies and their international relations [1]. Tourism delivers large amounts of revenue into the economy in the form of spending on goods and services, which are essential for tourists. As per the World Tourism Organisation, $10 \%$ of the World's GDP is contributed by the Travel and tourism industry, and one out of every ten jobs are related to the industry [2]. Travel and Tourism Industry accounts for almost 1.4 trillion U.S. dollars, which are $7 \%$ of the World's exports and $30 \%$ of services exports [2].

Sri Lanka is often considered as an increasingly popular destination for international tourists, as well as for expatriates who return home to visit relatives and friends. Lonely Planet ranked Sri Lanka as the number one destination to visit in 2013. In 2015, Forbes magazine declared Sri Lanka among the "top ten coolest countries" to visit [3]. Also, in 2016 Lonely Planet, Rough Guides, The Guardian, The New York Times have identified Sri Lanka as a top location to visit [4]. Travel and Tourism Industry is the third-largest export earner in the Sri Lankan Economy, after remittances, textiles and garments. At present Sri Lanka is experiencing unprecedented growth in visitors, averaging more than $22 \%$ year on year [4]. First-time in 2016, Tourism in Sri Lanka has surged to a milestone of over 2 million tourists arrival, which is a remarkable increase of $14 \%$ over 1.8 million tourist arrivals in 2015 [5]. In 2016, international visitors stayed an average of 10.2 nights and generated 3.5 million U.S. dollars [5]. Asian visitors continued to be the primary source of tourism in Sri Lanka, accounting $45.1 \%$ of the total share, followed by Western Europe with a share of $31.4 \%$ [5]. The occupancy rate of graded accommodation has shown $74.76 \%$ where the total guest nights recorded in tourist hotels has increased to 10.6 million nights in 2016 which is an 18.4\% of growth compared with 2015 [5].

Tourism is a highly dynamic and competitive industry, which requires the ability to continually adapt to tourists' rapidly changing needs and desires, as the tourist's satisfaction, safety, and enjoyment are the prime focus of travel and tourism industry. In order to make Sri Lanka competitive in the global Travel and Tourism marketplace and to utilize the full potential of the industry to the economy, right policies and investment decisions are essential. The Sri Lanka Tourism Strategic Plan 2017-2020 is a significant step taken by the Ministry of Tourism Development and Christian Religious Affairs in this regard. However, it is perhaps one of the curious anomalies of travel and tourism studies as strange that more academics have not devoted their attention to the impacts surrounding real estate development. In the end, real estate is fundamental to tourist experiences, whether it is in the form of accommodation at a 
luxury five-star hotel complex, the excitement of a theme park, or obviously, walking through an untouched wilderness area. Real estate is vital to the tourism business, simultaneously, as a principal asset and a major source of costs [6]. Destination development is in no small measure a function of the resolution of real estate markets among competing land uses.

\section{PURPOSE OF THE STUDY}

This paper aims to examine the economic importance of tourism and review the major trends that are shaping the growth and development of the Travel and Tourism Industry.

\section{THE SIGNIFICANCE OF THE STUDY}

2017 was declared as the International Year of Sustainable Tourism for Development by United Nations General Assembly recalling the potential of tourism to advance the universal 2030 Agenda for Sustainable Development and the 17 Sustainable Development Goals (SDGs) [7]. The International Year aims to sustain a change in policies, business practices and consumer behaviour towards a more sustainable tourism sector that can contribute effectively to the SDGs. This opportunity is fitting for Sri Lanka as the country embarks on a journey of transformation of its tourism sector.

This paper aims to explore emerging trends in Travel and Tourism Industry in Sri Lanka; a region that has seen high growth and contribution to the local economy in many ways over the recent years and is poised to be the centre of tourism soon. Knowledge gaps are identified as an agenda for future research to understand better tourism and its impact on real estate development in Sri Lanka.

This research also aims to provide a guide for academic researchers to identify future research opportunities in Sri Lankan Travel and Tourism Industry that will be of benefit to policymakers, academia, industry and for the wider society.

\section{OBJECTIVES}

\section{A. General Objective}

To analyse major trends associated with the Travel and Tourism Industry and its impact on real estate development in Sri Lanka.

\section{B. Specific Objectives}

To analyse the performance of key economic indicators related to the Travel and Tourism Industry in Sri Lanka.

To identify the importance of the Travel and Tourism Industry towards real estate development in Sri Lanka.

\section{Methodology}

The Contribution of the Travel and Tourism Industry can be explained using Tourism Satellite Account: Recommended Methodological Framework 2008 (TSA: RMF 2008) published by Statistics division of the World Tourism Organization [8]. According to TSA: RMF 2008, the framework only recognizes the direct contribution of Travel and tourism industry. Nevertheless, the industry has significant indirect and induced impacts which were overlooked in the framework. World Travel and Tourism
Council recognize those indirect and induced impacts through its researches [9]. This study follows the modified TSA: RMF 2008 (Figure 1) published by World Travel and Tourism Council in order to identify and explain the economic importance and trends of the Travel and Tourism Industry in Sri Lanka.
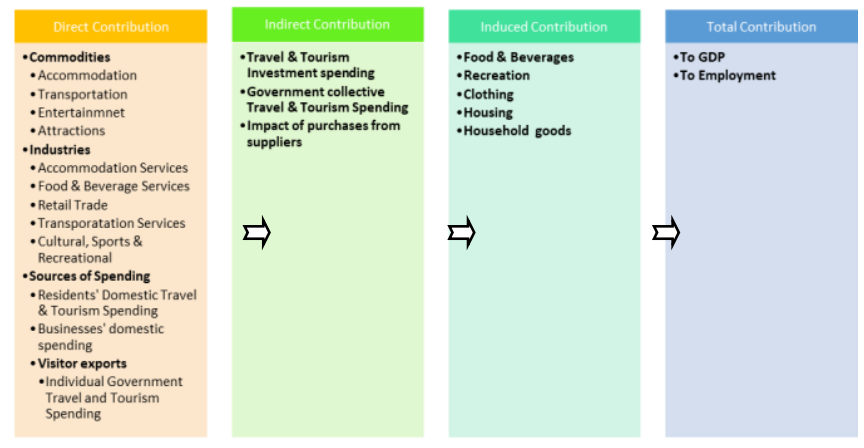

Fig. 1. Tourism Framework 2008

The trends were identified through a review of published journal articles, annual and quarterly reports published by United Nations' World Tourism Organization, World Travel and Tourism Council, World Economic Forum and Sri Lanka Tourism Development Authority and through a descriptive analysis of the raw data obtained from Data Gateway of World Travel and Tourism Council [10].

\section{LIMITATIONS}

1. The trends were identified by using the performance of selected key economic indicators of the Travel and Tourism Industry.

2. The results that have been concluded are based on the data and information available for Sri Lanka, and it might be not the same for other countries or regions.

\section{LITERATURE REVIEW}

As the article focuses on trends, a brief review of trend identification in the Travel and Tourism Industry is provided here. According to Tolkach et al., (2016), a change can be described using three different key terms; "fad", "trend" and "Megatrend". "Fad" is a change for a short period devoid of any significance or societal insinuations [11]. "Trend" is a phenomenon which is of most enormous significance on society that is typically long-lasting. The term "trend" has to turn out to be a common term and may be applied to changes in diverse contexts and the phenomena of significance [12]. The term "Megatrend" has been defined by the Oxford Dictionary, 2018, as an "important shift in the progress of a society or of any other particular field or activity; any major movement" which will have higher and long-lasting impacts than trends. The period of trends typically ranges from 1 to 2 years, where it may extend for a decade and beyond [13].

Trends analysis methods involve quantitative analysis of statistical data and survey results and qualitative analysis of interviews [11]. Peng, Song \& Crouch, 2014 states that the quantitative approaches are more well known in modelling 
and forecasting demand. However, the drawback of the dependence on historical data to predict future might be unreliable because of the varying political, social and economic situations in addition to unexpected disasters [14]. In the case of qualitative approach, researchers like Tolkach et al., (2016); Ballantyne et al., (2009); Buckley et al., (2015); Tribe, (2008); Xiao and Smith, (2006), adopt the content analysis to explore trends in the tourism sector [11] [15] [16] [17] [18].

Various leading industry organizations have been analysing travel and tourism trends. For example, the United Nations' World Tourism Organization annually publishes Tourism Highlights which identify arrivals and expenditure. Also, the World Tourism and Travel Council focus on long-term trends in the economic impact of travel and tourism activities and publishes monthly updates. Pacific Asia Travel Association (PATA) a leading organization in the region, publishes thematic reports on regional travel-related issues and trends. Jones Lang LaSalle Incorporated (JLL) which is a professional service and investment management company specializing in real estate, also publishes annual reports on the trends and performance of the travel and tourism industry. As the local apex body related to travel and tourism, Sri Lankan Tourism Development Authority (SLTDA) also publishes reports on the performance and trends of the Travel and Tourism Industry in Sri Lanka.

\section{DATA ANALYSIS}

\section{A. Direct Spending Impacts}

\section{1) Visitor Exports}

As per the Tourism Satellite Account: Recommended Methodological Framework 2008 (TSA: RMF 2008), Visitor Exports is the spending within the country by international tourists for both leisure and business trips, including spending on transport. International spending on education is excluded. This is consistent with the total inbound tourism expenditure explained in the TSA: RMF 2008.

After the civil war ended in 2009, Visitor Exports in Sri Lanka have dramatically increased over time wherein 2017 Travel and Tourism Industry has generated LKR 725.2 billion Visitor Exports which is $25.3 \%$ of total exports in 2017. Moreover, it is expected to grow by $5.1 \%$ per annum in 2018 and will continue to rise by $6.6 \%$ per annum from 2018 to 2028 to LKR 1445.7 billion by 2028 (30.2\% of total exports).

Fig. 2. Visitor Exports

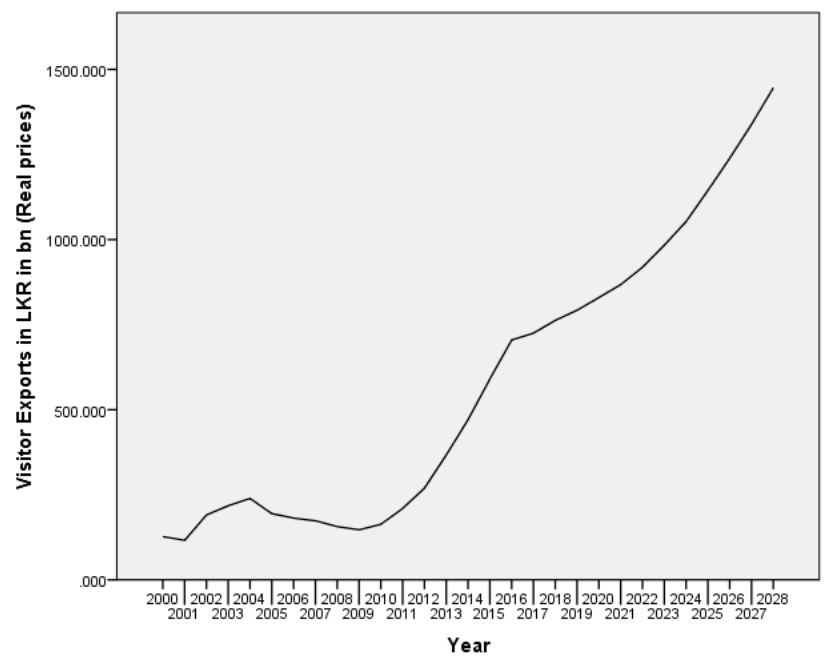

Source: Compiled by Author using WTTC Data, 2018

\section{2) Domestic Travel and Tourism Spending}

Spending within a country by that country's residents for both business and leisure trips are considered as Domestic Travel and Tourism Spending. However, multi-use consumer durables are not included since they are not purchased solely for tourism purposes. This is consistent with total domestic tourism expenditure explained in the TSA: RMF 2008. Also, Outbound spending by residents abroad is not included and is separately identified according to the TSA: RMF 2008.

There has been a steady growth in Domestic Travel and Tourism Spending over the years, except for some drop in 2010 and 2013. Travel and Tourism Industry has recorded LKR 381.8 billion Domestic Travel and Tourism Spending. Furthermore, it is expected to grow by $4.2 \%$ per annum in 2018 and will continue to rise by $3.9 \%$ per annum from 2018 to 2028 to LKR 584.6 billion by 2028 .

Fig. 3. Domestic Travel and Tourism Spending

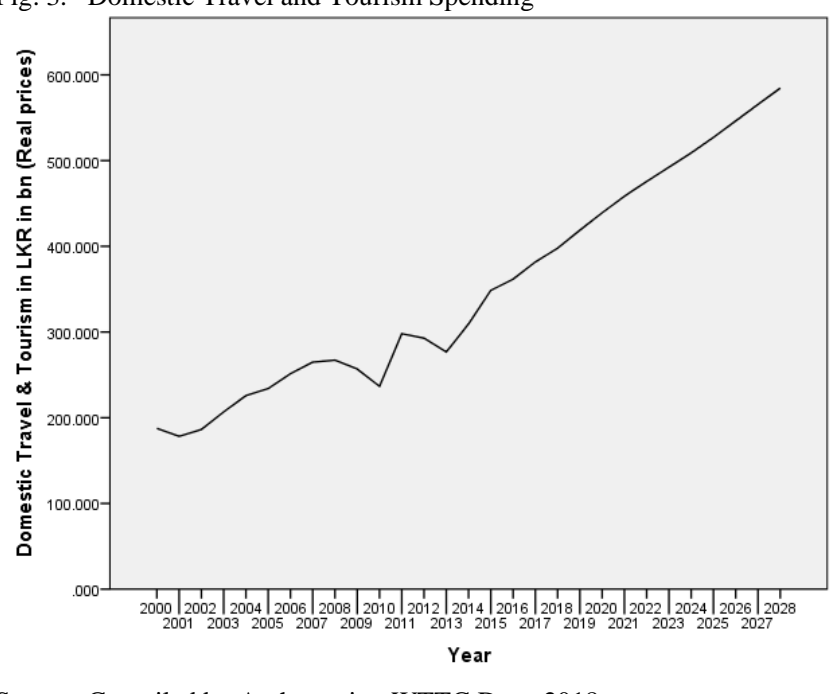

Source: Compiled by Author using WTTC Data, 2018

3) Government Individual Spending

According to Tourism Satellite Account: Recommended Methodological Framework 2008 (TSA: RMF 2008), government spending on travel and tourism services directly 
linked to visitors. For example, cultural services (museums) or recreational services (e.g. national parks) is identified as Government Individual Spending.

Over the past 17 years, Government Individual Spending on Travel and Tourism Industry has shown a sharp growth except in 2010, recorded a significant drop. However, from 2011 the trend has continued to grow where in 2017 Government Individual Spending was LKR 6.8 billion. Furthermore, it is expected to grow by $4.5 \%$ per annum in 2018 and will continue to rise by $5.5 \%$ per annum from 2018 to 2028 to LKR 11.4 billion by 2028 .

Fig. 4. Government Individual Spending

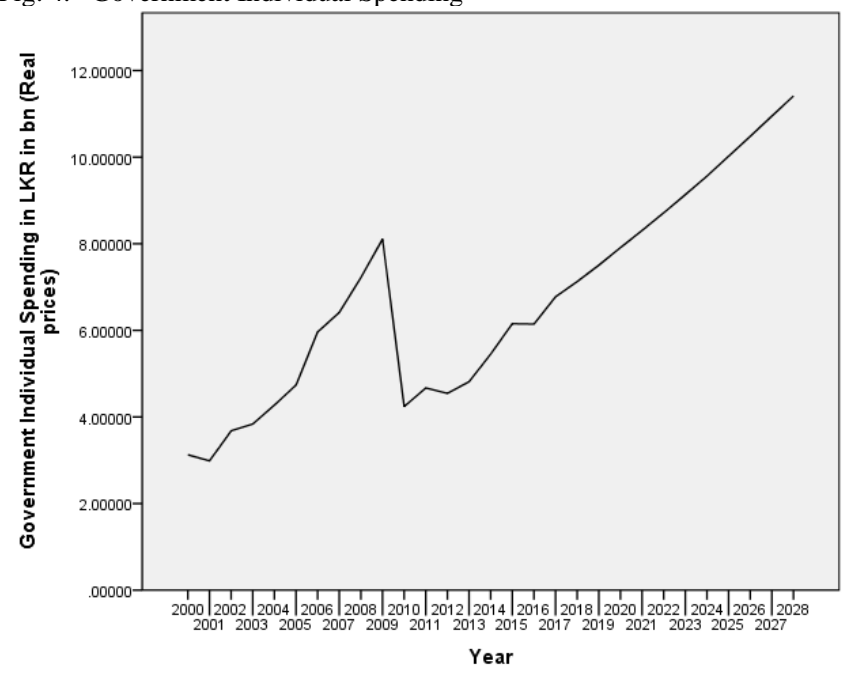

Source: Compiled by Author using WTTC Data, 2018

\section{4) Internal Tourism Consumption}

Internal Tourism Consumption is the total revenue generated within a country by industries that deal directly with tourists, including visitor exports, domestic spending, and government individual spending. This does not include spending abroad by residents. This is consistent with total internal tourism expenditure explained in the TSA: RMF 2008.

In overall Internal Tourism Consumption in Sri Lanka has shown steady growth as in 2017, it was LKR 1107 billion. Furthermore, it is expected to grow by $4.8 \%$ per annum in 2018 and will continue to rise by $5.8 \%$ per annum from 2018 to 2028 to LKR 2030.3 billion by 2028 .

Fig. 5. Internal Tourism Spending

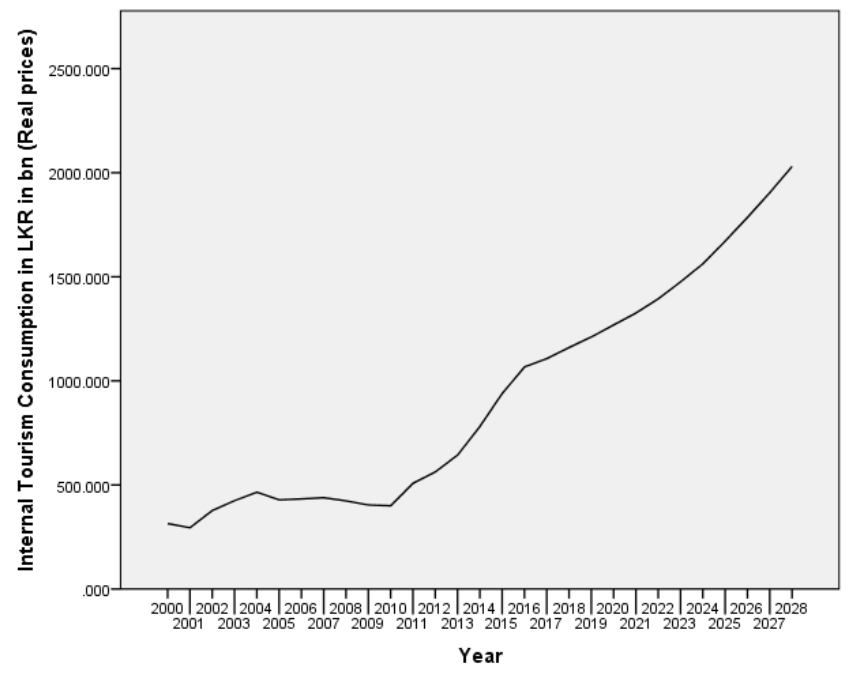

Source: Compiled by Author using WTTC Data, 2018

5) Business Travel and Tourism Spending

Spending on business travel within a country by residents and international visitors is represented in Business Travel and Tourism Spending. As per the figure below, there has been a dramatic increase in Business Travel and Tourism Spending after 2009, and in 2017, Business Travel and Tourism Spending was LKR 229.9 billion. Furthermore, it is expected to grow by $4.9 \%$ per annum in 2018 and will continue to rise by $4.8 \%$ per annum from 2018 to 2028 to LKR 399.6 billion by 2028.

Fig. 6. Business Travel and Tourism Spending

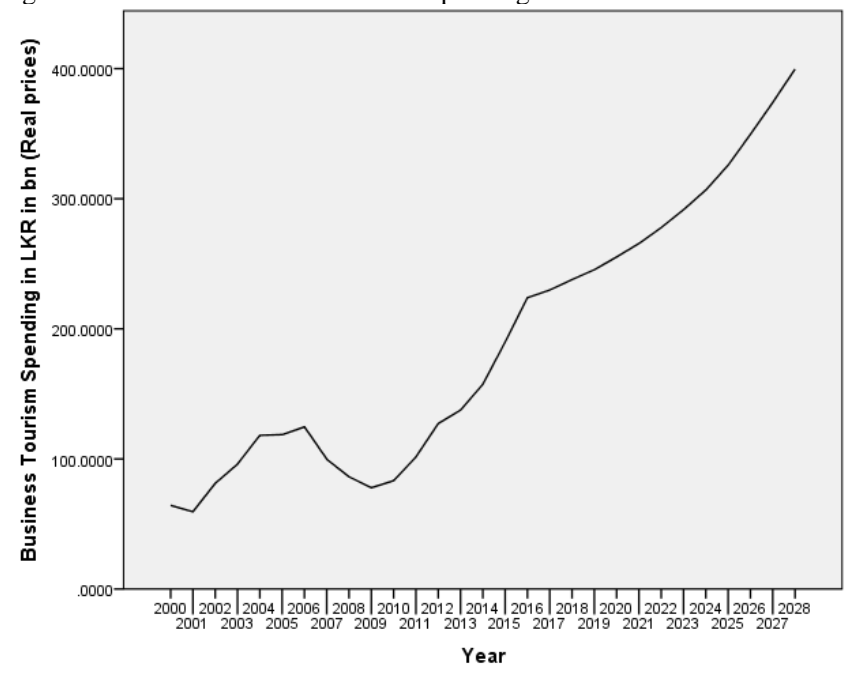

Source: Compiled by Author using WTTC Data, 2018

6) Leisure Travel and Tourism Spending

Leisure Travel and Tourism Spending consist of spending on leisure travel within a country by residents and international visitors. There has been a significant increase in Leisure Travel and Tourism Spending after 2009, and in 2017, it was LKR 877.1 billion. Furthermore, it is expected to grow by $5.2 \%$ per annum in 2018 and will continue to rise by $5.9 \%$ per annum from 2018 to 2028 to LKR 1631 billion by 2028 . 
Fig. 7. Leisure Travel and Tourism Spending

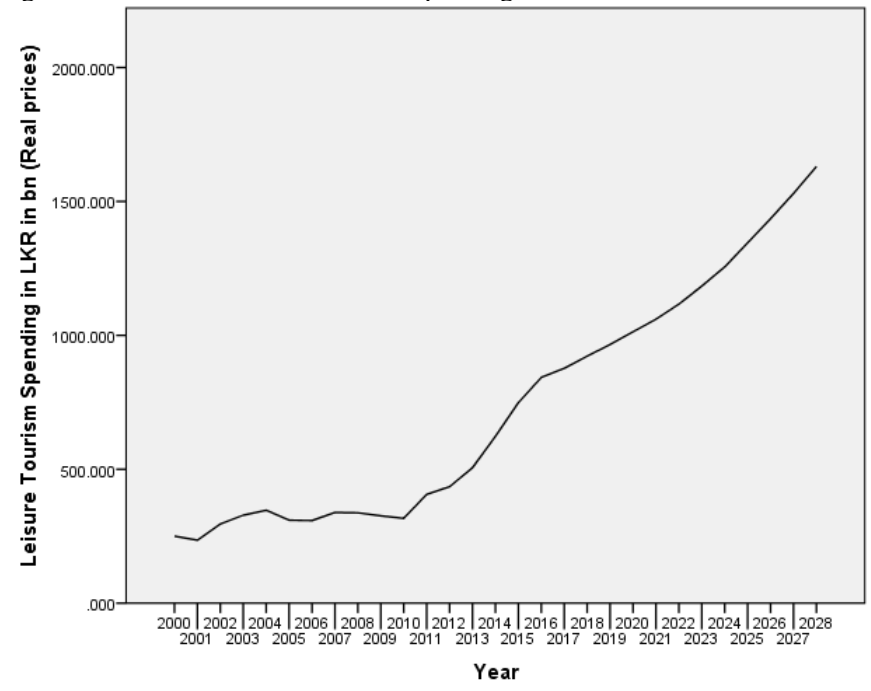

Source: Compiled by Author using WTTC Data, 2018

\section{B. Indirect and Induced Impacts}

\section{1) Capital Investment}

Capital Investment includes capital investment spending by all industries directly involved in Travel and Tourism. This also constitutes investment spending by other industries on specific tourism assets such as new visitor accommodation and passenger transport equipment, as well as restaurants and leisure facilities for specific tourism use. This is consistent with total tourism gross fixed capital explained in the TSA: RMF 2008.

There has been significant growth in Capital Investment in the Travel and Tourism Industry after 2010, and in 2017, it was LKR 144.3 billion. Furthermore, it is expected to grow by $4.3 \%$ per annum in 2018 and will continue to rise by $3.1 \%$ per annum from 2018 to 2028 to LKR 203.5 billion by 2028 .

Fig. 8. Capital Investment

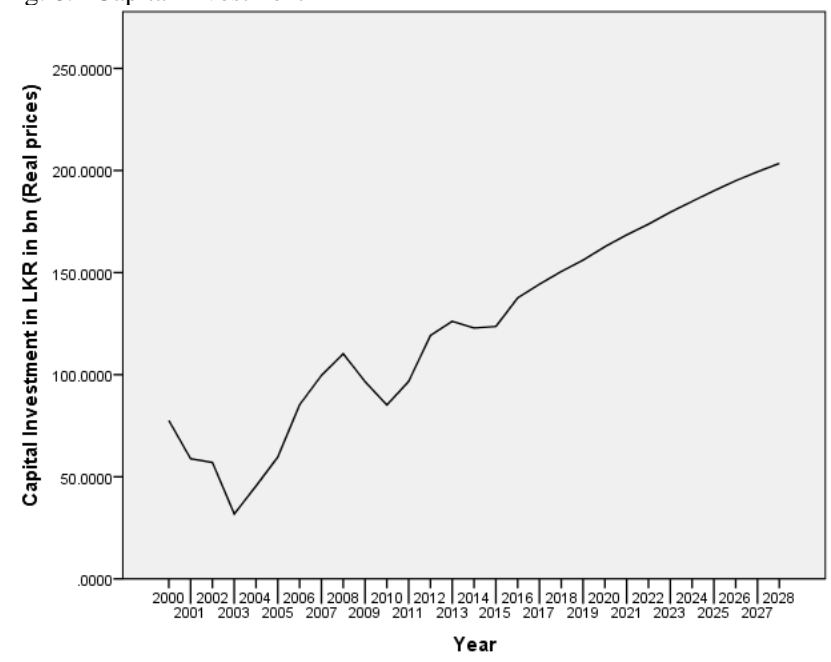

Source: Compiled by Author using WTTC Data, 2018

2) Government Collective Spending

Government Collective Spending is the government spending in support of general tourism activity. This can include national as well as regional and local government spending. For example, it includes tourism promotion, visitor information services, administrative services and other public services. This is consistent with total collective tourism consumption explained in the TSA: RMF 2008.

Government Collective Spending has shown steady growth over the years as in 2017, and it was LKR 46.4 billion. Furthermore, it is expected to grow by $5.2 \%$ per annum in 2018 and will continue to rise by $4.8 \%$ per annum from 2018 to 2028 to LKR 78.2 billion by 2028 .

Fig. 9. Government Collective Spending

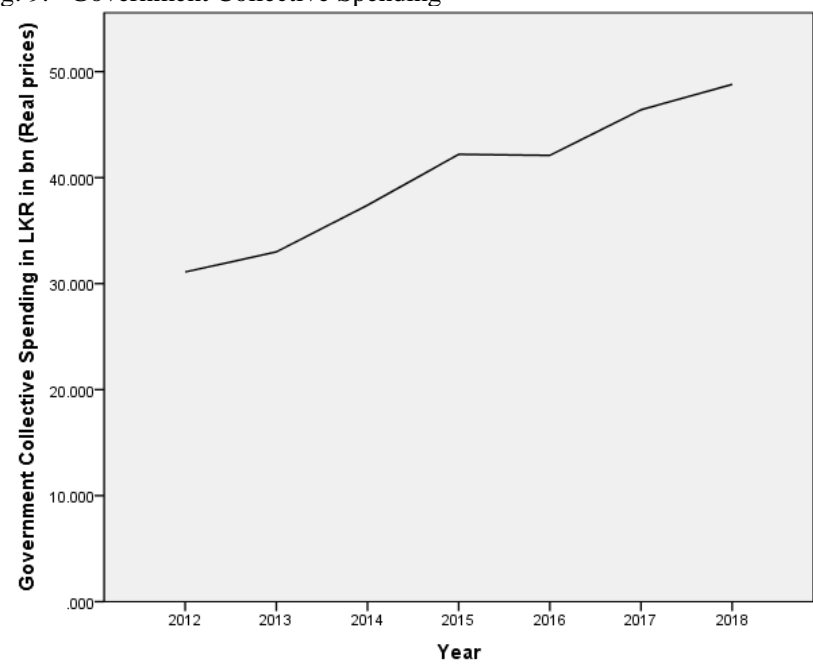

Source: Compiled by Author using WTTC Data, 2018

\section{3) Supply-Chain Effects}

Supply-Chain Effects consists of purchases of domestic goods and services directly by different industries within the Travel and Tourism as inputs to their final tourism output. As years went by, Supply-Chain Effects have shown continuous growth as in 2017, and it was LKR 355.7 billion. Furthermore, it is expected to grow by $5.1 \%$ per annum in 2018 and will continue to rise by $5.7 \%$ per annum from 2018 to 2028 to LKR 373.6 billion by 2028 .

Fig. 10. Supply Chain Effect

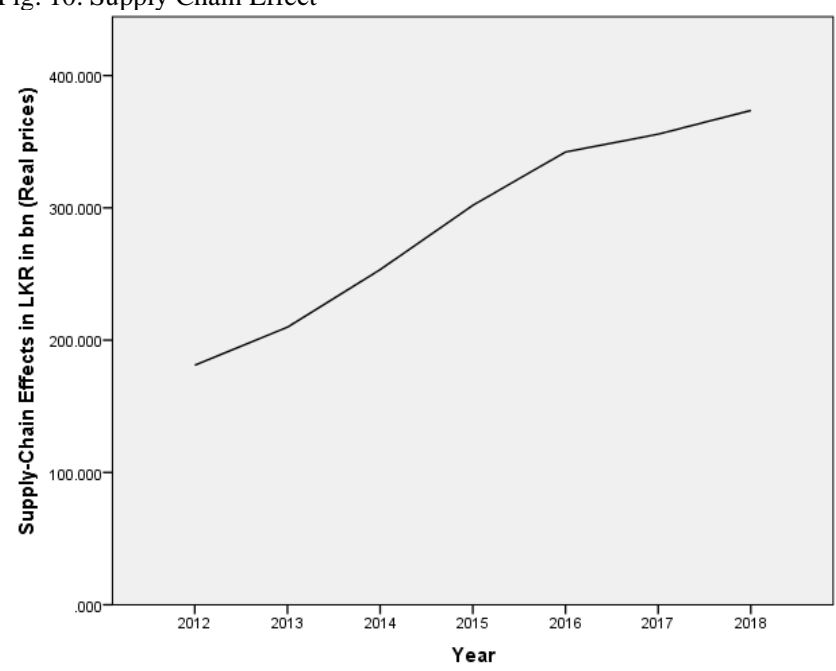

Source: Compiled by Author using WTTC Data, 2018

\section{Direct Contribution to GDP}

Direct Contribution to the GDP is the GDP generated by industries that deal directly with tourists, including hotels, 
travel agents, airlines and other passenger transport services, as well as the activities of restaurant and leisure industries that deal directly with tourists. Which is equivalent to total internal Travel and Tourism Spending within a country less the purchases made by those industries (including imports). In terms of the UN's Tourism Satellite Account methodology, it is consistent with the total GDP explained in the TSA: RMF 2008.

Direct Contribution to GDP by the Travel and Tourism Industry has shown exponential growth over the years since 2010. Where Travel and Tourism Industry has directly contributed LKR 687.4 billion to GDP, which is $5.3 \%$ of Total GDP in 2017. Moreover, it is forecasted to grow by $5.1 \%$ in 2018 and continue to grow by $5.7 \%$ per annum from 2018 to 2028 which will be LKR 1,260 billion by 2018 (5.7\% of total GDP).

Fig. 11. Direct Contribution to GDP

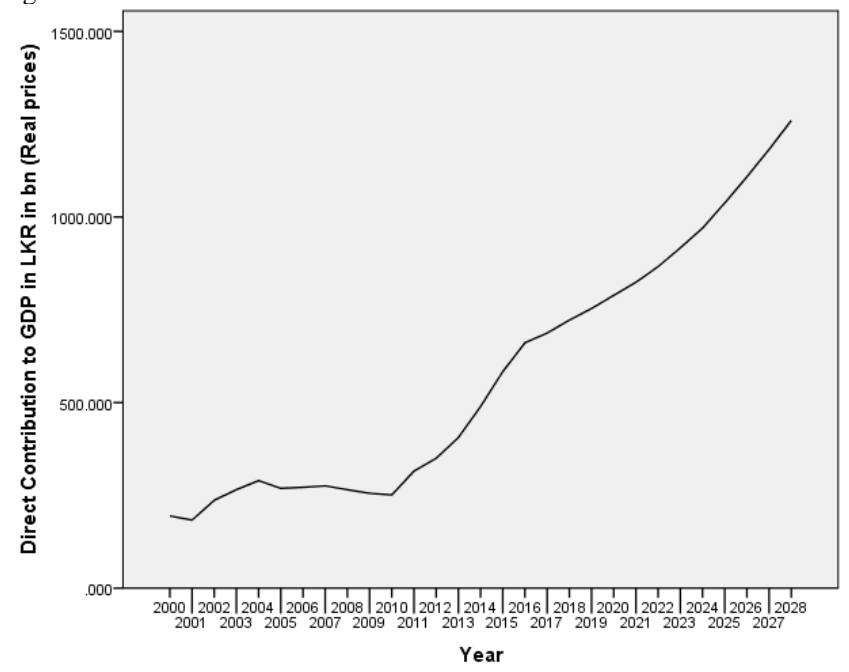

Source: Compiled by Author using WTTC Data, 2018

\section{Direct Contribution to Employment}

Direct Contribution to Employment is the number of direct jobs within Travel \& Tourism. This is consistent with total employment explained in the TSA: RMF 2008. Since 2010, the Travel and Tourism Industry has shown significant growth, directly creating employment opportunities. In 2017, the Travel and Tourism Industry directly supported 404,000 jobs which are $5.1 \%$ of total employment. It has been forecasted to grow by $3.7 \%$ in 2018 and continue to rise by $2.2 \%$ per annum up to 522,000 jobs by 2028 .

Fig. 12. Direct Contribution to Employment

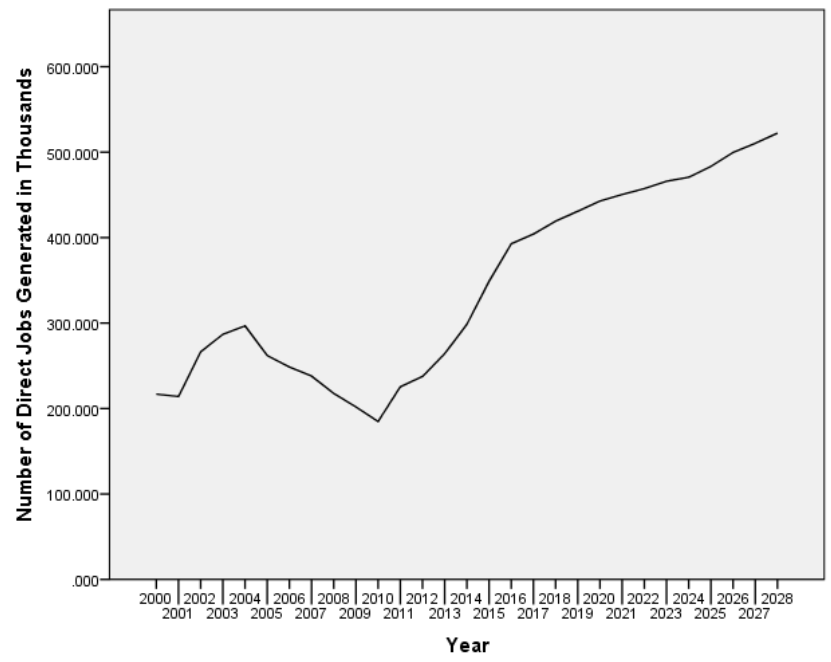

Source: Compiled by Author using WTTC Data, 2018

\section{E. Total Contribution to GDP}

Total Contribution to GDP is the GDP generated directly by the Travel and Tourism sector, plus its indirect and induced impacts. Travel and Tourism Industry's total contribution to GDP has shown a continuous growth after the end of civil war in 2009. The total contribution of Travel and Tourism Industry to GDP was LKR 1518.8 billion, which is $11.6 \%$ of GDP in 2017 and expected to rise by $5.1 \%$ in 2018 and continue to rise by $5.5 \%$ per annum where it will be LKR $2,714.1$ billion by 2028 (12.3\% of GDP).

Fig. 13. Total Contribution to GDP

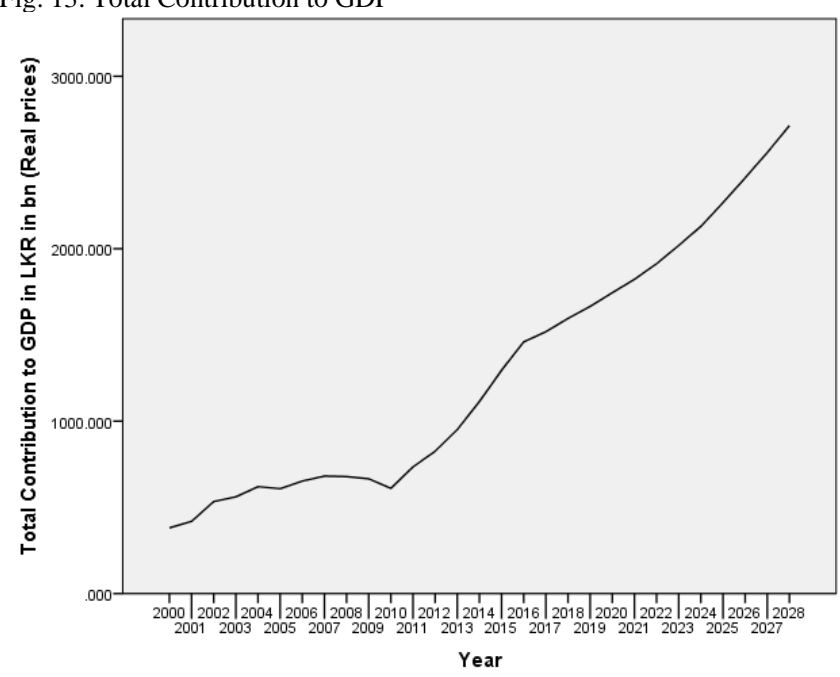

Source: Compiled by Author using WTTC Data, 2018

\section{F. Total Contribution to Employment}

The number of jobs generated directly in the Travel and Tourism Sector, including the contributions of indirect and induced sectors. Total Contribution to Employment has shown steady growth over the past seven years since the end of civil war. The total contribution of Travel and Tourism Industry to employment, including jobs indirectly supported by the Travel and Tourism Industry, was 875,000 jobs which are $11 \%$ of total employment in 2017. Furthermore, this is expected to grow by $2.6 \%$ in 2018 and continue to grow by $1.5 \%$ per annum to $1,037,000$ jobs by $2028(12.8 \%$ of total employment). 
Fig. 14. Total Contribution to Employment

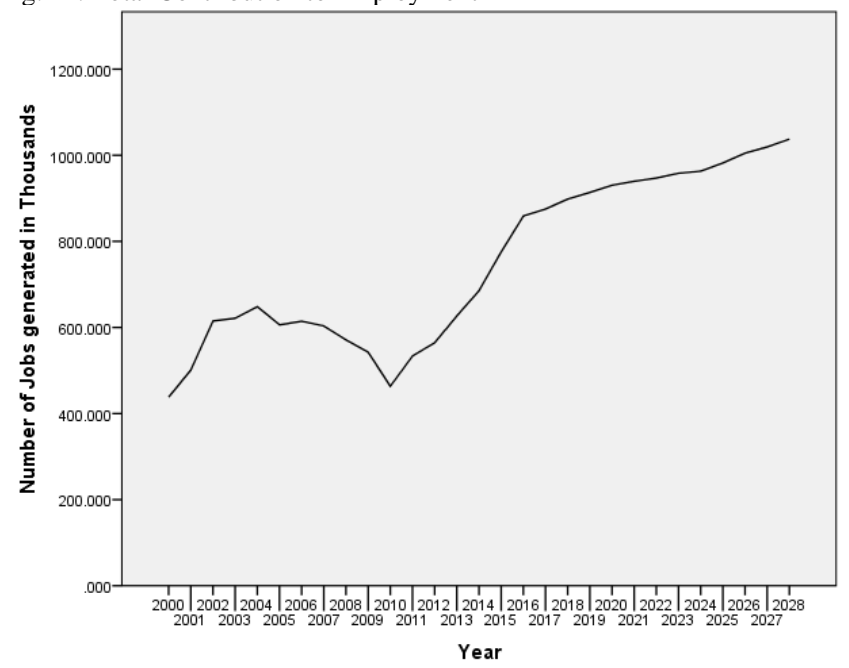

Source: Compiled by Author using WTTC Data, 2018

\section{G. Real Estate Trends in Travel and Tourism Industry}

Real Estate is central to the Travel and Tourism Industry, so it is not exaggerating to state that the Travel and Tourism Industry has been built around Real Estate. Similarly, developing the Travel and Tourism Industry is an activity of Real Estate Development. As every commodity associated with the industry; Accommodation, Transportation, Entertainment and Attractions are fundamentally a piece of Real Estate.

Real Estate Hotspots such as Colombo, Kandy, and Galle [19] in Sri Lanka are also the countries' most preferred travel destinations. As these destinations charm more and more tourists, the demand for better tourism commodities such as accommodation, entertainment, and retail will expand. Moreover, Sri Lanka has achieved an important landmark of 2 Million international tourist arrivals in 2016 [20]. Sri Lanka has performed well in terms of attracting foreign revenue as, IHS Incorporation; a global information company in the United States has listed Sri Lanka among the top 10 FDI hotspots in 2016 [21]. At present, many local and international companies, namely Jetwing Hotels Limited, Cinnamon Hotels by John Keels Holdings, Shangri-La Group; a premier Asian luxury hotel chain, ITC Group of India, Thailand's Minor Group, RIU Hotels \& Resorts in Spain, Singapore's Aman Resorts, etc., have already made investments to expand Travel and Tourism Industry in Sri Lanka [22]. In order to facilitate the increasing number of tourists, the government of Sri Lanka has invested in developing necessary public infrastructure to facilitate easy transportation links between prime cities such as Colombo, Kandy, Gampaha and Galle. The first-ever expressway from Colombo to the southern hub of Galle in 2011 and the Colombo to Katunayake expressway in 2013 are such endeavours. Furthermore, highways from Katunayake to Anuradhapura, Anuradhapura to Jaffna and Colombo to Kandy are in progress.

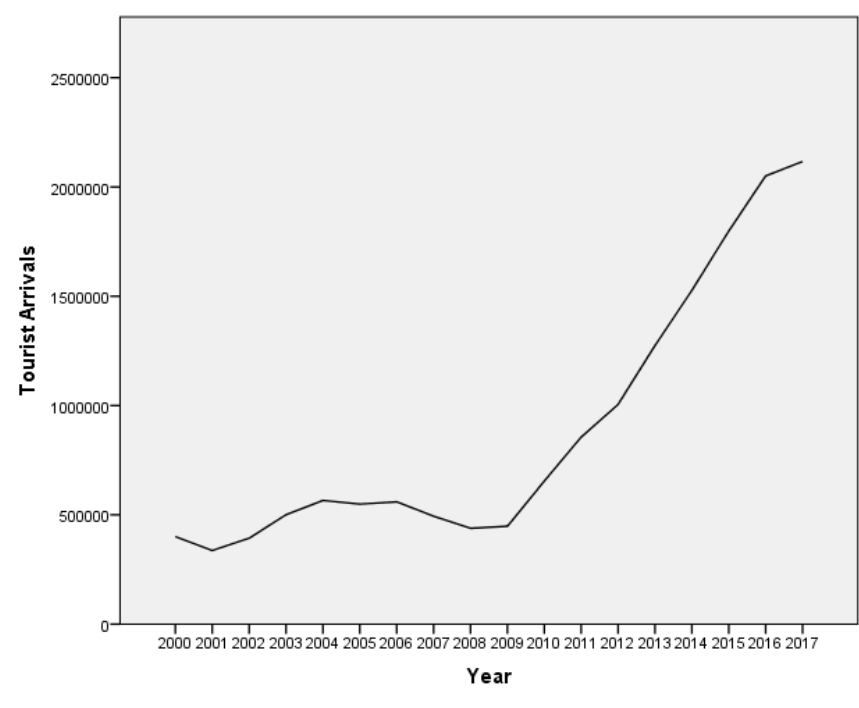

Source: Compiled by Author using Sri Lanka Tourism Promotion Bureau Data, 2018

In terms of accommodation capacity, the total number of Sri Lanka Tourism Development Authority (SLTDA) registered accommodation establishments as at 30th June 2018 was 2,164 [23]. The number of classified or graded tourist hotels was 136, and among them, 22 were five-star hotels. Importantly the presence of small and medium enterprises is strong in the hospitality market with guesthouses, homestays and bungalows recording the highest number of registered establishments with 904, 395 and 354 units respectively. The total room inventory was 36,381, and Classified tourist hotels (1-5 star) had the highest inventory of 12,822 rooms.

Fig. 16. Accommodation Capacity (Graded Rooms)

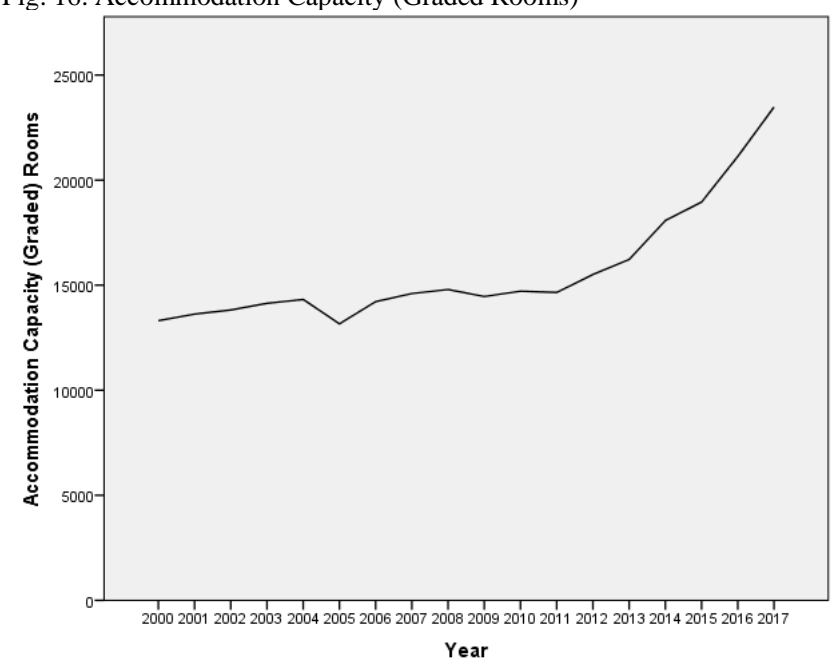

Source: Compiled by Author using Sri Lanka Tourism Promotion Bureau Data, 2018

According to the Figure 17, Formal Tourist Accommodation establishments, including Star Class Hotels \& Other Supplementary Establishments like Boutique Hotels, Guest Houses, Bungalows have an occupancy level around $70 \%$ in recent years [5].

Fig. 15. International Tourists Arrivals 
Fig. 17. Annual Room Occupancy Rate

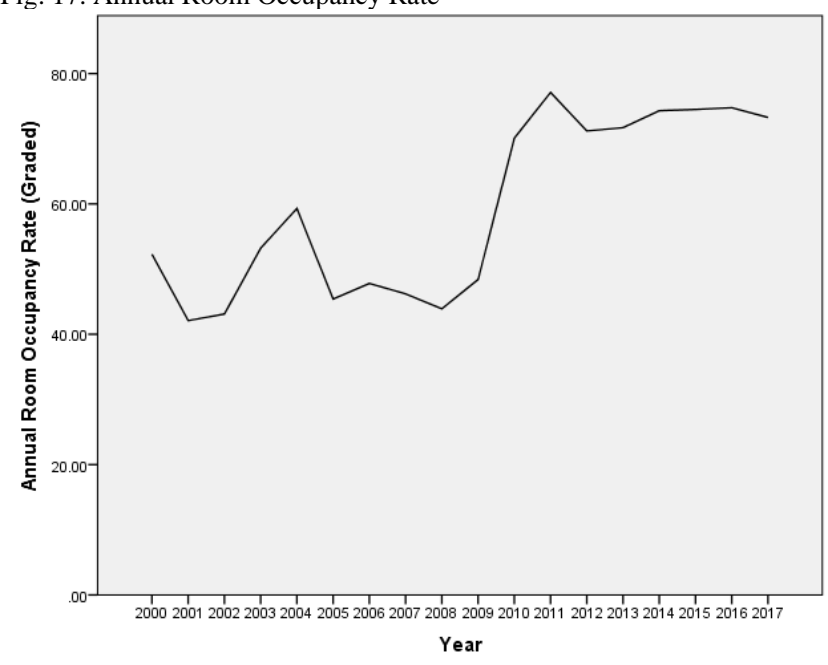

Source: Compiled by Author using Sri Lanka Tourism Promotion Bureau Data, 2018

Table I depicts the number of investment projects handled by SLTDA up to end June 2018 [23]. A sum of 326 projects had been granted final approval while 115 are under construction and 171 are in operation. Moreover, 40 tourism investment projects are yet to be commenced. The number of rooms of final approval granted projects is 18,364 . The total investment value of final approval granted projects is estimated at USD 2,895.3 million. The value of projects which are under construction is USD 1,044.2 million. Moreover, the investment value of projects in operation is USD 1,640 million, while the value of projects that have not commenced is USD 181.6 million.

TABLE I. THE PROGRESS OF INVESTMENT PROJECTS - UP TO END JUNE 2018*

\begin{tabular}{|l|c|c|c|}
\hline Status of the Projects & $\begin{array}{c}\text { No. of } \\
\text { Projects }\end{array}$ & $\begin{array}{c}\text { No. of } \\
\text { Rooms }\end{array}$ & $\begin{array}{c}\text { Investment Value } \\
\text { (USD mn) }\end{array}$ \\
\hline Final approval granted & 326 & 18,364 & $2,895.3$ \\
\hline Under construction & 115 & 7,460 & $1,044.2$ \\
\hline Projects in operation & 171 & 9,143 & $1,640.0$ \\
\hline Projects not yet started & 40 & 1,761 & 181.6 \\
\hline
\end{tabular}

Source: SLTDA, 2018

Among the final approval granted projects, there are 22 tourism investment projects with accommodation of over 200 rooms [23]. The highest number of projects (221) are those with less than 49 rooms [23].

TABLE II. ROOM DISTRIBUTION OF FINAL APPROVAL GRANTED PROJECTS - UP TO END JUNE 2018*

\begin{tabular}{|l|c|c|}
\hline \multicolumn{1}{|c|}{ No. of Rooms } & No. of Projects & Percentage (\%) \\
\hline Over 200 & 22 & 6.8 \\
\hline $100-200$ & 19 & 5.8 \\
\hline $50-99$ & 64 & 19.6 \\
\hline Less than 49 & 221 & 67.8 \\
\hline Total & $\mathbf{3 2 6}$ & $\mathbf{1 0 0}$ \\
\hline
\end{tabular}

Source: SLTDA, 2018

The majority of tourists (83.4\%) visit Sri Lanka for pleasure or holiday [5]. According to Sri Lanka Tourism Development Authority, (2017), the total number of nights spent by the 2,050,832 tourists who visited the country in 2016 amounted to 20,918,486. Foreign Tourist Nights recorded in Informal Accommodations or Unregistered
Accommodation units amounted to 4,918,786 nights in 2016, which was an increase of $1.02 \%$ compared to $4,868,945$ nights recorded in 2015. As a percentage about $23.51 \%$ of tourist had utilized unregistered accommodation units. It is noteworthy that out of total tourist nights spent by tourists who visited Sri Lanka, about $25.84 \%$ was spent in supplementary establishments (Boutique Villa, Guest Houses, Rest Houses, Home Stay Units, Tourist Bungalows, Rented Tourist Homes, Rented Tourist Apartments and Heritage Bungalows / Homes etc.). It is a significant change in the trend of tourist stay during the last couple of years where guest nights spend in both supplementary and informal establishments has been increasing. Such a trend will encourage investment in small boutique hotels and tourist bungalows in the future.

Fig. 18. Percentage of Guest Nights spent in Tourist Accommodation Establishments

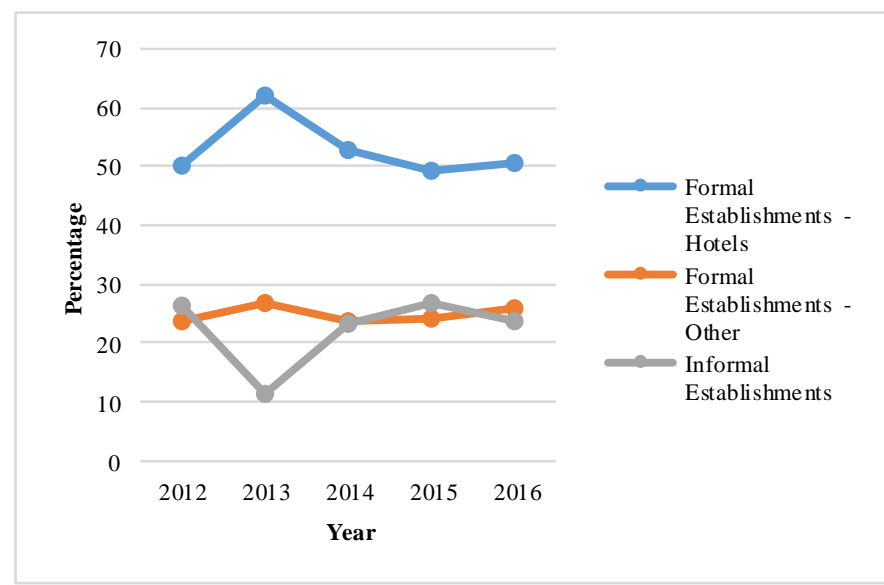

Source: Compiled by Author using Sri Lanka Tourism Development Authority Data, 2018

Some Thoughts for future research on Tourism Friendly Real Estate in Sri Lanka;

- Real Estate Development and Management should incorporate with global concerns on SMART Real Estate, Building Information Modelling (BIM), Internet of Things (IoT), Going Green, Social Harmony, Human Rights, to maintain and support Sustainable Travel and Tourism Industry [24] [25].

- Evaluation of Conventional Travel and Tourism Industry towards Unconventional Travel and Tourism Industry drove by digital disruptions such as Airbnb. In this regard, what should be the shape of Real Estate and related Services? [26].

- Developing proper standards for tourist accommodation establishments specifically for basic facilities such as washrooms, drinking water, waste disposal, clarity of premises, the quality of restaurants, the natural beauty of streets and avenues, accidents and disaster management.

- Tourism development should lead to encourage visitors to stay longer and visit more places around the island, broadening the sector's geographic impact. In this regard, a planned real estate development is necessary. 


\section{FINDINGS \& CONCLUSION}

1. Travel and Tourism Industry has directly contributed LKR 687.4 billion to GDP, which is $5.3 \%$ of Total GDP in 2017. It is forecasted to grow by $5.1 \%$ in 2018 and continue to grow by $5.7 \%$ per annum from 2018 to 2028, which will be LKR 1,260 billion by 2018 (5.7\% of total GDP).

2. The total contribution of Travel and Tourism Industry to GDP was LKR 1518.8 billion, which is $11.6 \%$ of GDP in 2017 and expected to rise by $5.1 \%$ in 2018 and continue to rise by $5.5 \%$ per annum where it will be LKR 2,714.1 billion by 2028 (12.3\% of GDP).

3. In terms of employment, the Travel and Tourism Industry has directly supported 404,000 jobs which are $5.1 \%$ of total employment in 2017. It has been forecasted to grow by $3.7 \%$ in 2018 and continue to rise by $2.2 \%$ per annum to 522,000 jobs by 2028 .

4. The total contribution of Travel and Tourism Industry to employment, including jobs indirectly supported by the Travel and Tourism Industry, was 875,000 jobs which are $11 \%$ of total employment in 2017. And this is expected to grow by $2.6 \%$ in 2018 and continue to grow by $1.5 \%$ per annum to $1,037,000$ jobs by $2028(12.8 \%$ of total employment).

5. Travel and Tourism Industry has generated LKR 725.2 billion visitor exports, which are $25.3 \%$ of total exports in 2017 . It is expected to grow by $5.1 \%$ per annum in 2018 and continue to rise by $6.6 \%$ per annum from 2018 to 2028 to LKR 1445.7 billion by 2028 (30.2\% of total exports).

6. Investments in the Travel and Tourism Industry was LKR 144.3 billion in 2017, which is $4.1 \%$ of total investment in 2017. It is expected to rise by $4.3 \%$ this year and will continue to grow by $3.1 \%$ per annum over the next decade to LKR 203.5 billion by 2028 (3.6\% of total investment)

7. Many local and international companies have already made investments which will expand the current accommodation capacity within the country.

8. A sum of 326 projects had been granted final approval while 115 are under construction and 171 are in operation. Moreover, 40 tourism investment projects are yet to be commenced.

9. The business segment is still small compared to leisure, accounting for $20.8 \%$ of tourism and travel GDP in 2017, according to data from the WTTC. In this regard Meetings, Incentives, Conferences and Exhibitions (MICE) tourism can be identified as an area for development.

10. Graded Tourist Accommodation establishments, including Star Class Hotels \& Other Supplementary Establishments like Boutique Hotels, Guest Houses, Bungalows have an occupancy level of around $70 \%$ in recent years.

11. Tourist nights were spent in Tourist Hotels is gradually declining while tourists' nights spent in supplementary establishments and unregistered accommodation units and private houses is increasing, which indicates the change of preferences in terms of tourist accommodation.

\section{REFERENCES}

[1] The World Tourism Conference, 1980. MANILA DECLARATION ON WORLD TOURISM. pp. 1-3.

[2] UNWTO, 2017. UNWTO Tourism Highlights.

[3] Abel, A., 2014. The 10 Coolest Places To Visit In 2015 [WWW Document]. Forbes. URL https://www.forbes.com/sites/annabel/2014/11/25/the-10-coolestplaces-to-visit-in-2015/2/\#b 7034d23064c (accessed 5.29.18).

[4] Ministry of Tourism Development and Christian Religious Affairs, 2017. Strategic Plan 2017-2020.

[5] Sri Lanka Tourism Development Authority, 2017. Annual Statistical Report 2016.

[6] Ariyawansa, R., 2016. Management of Real Estate; Principles of Real Estate Development \& Management, First. ed. Colombo.

[7] World Tourism Organization, 2017. 2017 is the International Year of Sustainable Tourism for Development | World Tourism Organization UNWTO [WWW Document]. Press Release. URL http://media.unwto.org/press-release/2017-01-03/2017-internationalyear-sustainable-tourism-development (accessed 5.10.18)

[8] United Nations, 2011. Tourism Satellite Account 2008: Recommended Methodological Framework (Studies in Methods (Ser. F)), Tourism Satellite Account 2008: Recommended Methodological Framework (Studies in Methods (Ser. F)).

[9] World Travel and TourismCouncil, 2018. Travel And Tourismeconomic Impact 2018 World.

[10] Munasinghe, L.M., 2020. Data for: Sri Lankan Travel and Tourism Industry: Recent Trends and Future Outlook Towards Real Estate Development. https://doi.org/10.17632/568VNRFVGR.1

[11] Tolkach, D., Chon, K.K.S., Xiao, H., 2016. Asia Pacific tourism trends: Is the future ours to see? Asia Pacific J. Tour. Res. 21, 10711084. https://doi.org/10.1080/10941665.2015.1118395

[12] Nordin, S., 2005. Tourism of tomorrow. Ostersund, Sweden Eur. Tour. Res. .... https://doi.org/10.13140/2.1.1422.7849Oxford Dictionary, 2018. Megatrend | Definition of megatrend in English by Oxford Dictionaries [WWW Document]. URL https://en.oxforddictionaries.com/definition/megatrend (accessed 7.30.18).

[13] Pan, S., Chon, K., Song, H., 2008. Visualizing Tourism Trends: A Combination of ATLAS.ti and BiPlot. J. Travel Res. 46, 339-348. https://doi.org/10.1177/0047287507308318

[14] Prideaux, B., Laws, E., Faulkner, B., 2003. Events in Indonesia: Exploring the limits to formal tourism trends forecasting methods in complex crisis situations. Tour. Manag. 24, 475-487. https://doi.org/10.1016/S0261-5177(02)00115-2

[15] Ballantyne, R., Packer, J., Axelsen, M., 2009. Trends in tourism research. Ann. Tour. Res. 36, 149-152. https://doi.org/10.1016/j.annals.2008.07.001

[16] Buckley, R., Gretzel, U., Scott, D., Weaver, D., Becken, S., 2015. Tourism megatrends. Tour. Recreat. Res. 40, 59-70. https://doi.org/10.1080/02508281.2015.1005942

[17] Tribe, J., 2008. The art of tourism. Ann. Tour. Res. 35, 924-944. https://doi.org/10.1016/j.annals.2008.07.003

[18] Xiao, H., Smith, S.L.J., 2006. Case studies in tourism research: A state-of-the-art analysis. Tour. Manag. 27, 738-749. https://doi.org/10.1016/j.tourman.2005.11.002

[19] Ariyawansa, R. \& Abeysinghe, M., 2017. Exploring Factors Affecting the Competitiveness of Kandy City as a Heritage Tourism Destination. Colombo, International Conference on Real Estate Management and Valuation 2017 (ICREMV-2017).

[20] Sri Lanka Tourism Promotion Bureau, 2018. Tourism Growth Trends - 1970 to 2017

[21] Daily Mirror, 2016. Sri Lanka among top 10 hotspots for FDI - Daily Mirror - Sri Lanka Latest Breaking News and Headlines [WWW Document]. Dly. Mirror. URL http://www.dailymirror.lk/108252/SriLanka-among-top-hotspots-for-FDI (accessed 8.18.18)

[22] LMD, 2017. Growth In Tourism And The Real Estate Sector In Sri Lanka | LMD [WWW Document]. LMD. URL https://lmd.lk/growthin-tourism-and-the-real-estate-sector-in-sri-lanka/ (accessed 8.18.18).

[23] SLTDA, 2018. Tourism Industry Report.

[24] Munasinghe, L., 2018. Digital Disruption and Digital Transformation in Real Estate Industry. https://doi.org/10.13140/RG.2.2.12373.99048 
[25] Munasinghe, L.M., Gunawardhana, T., Ariyawansa, R.G., 2018. Green Rating Systems for Built Environment and its Implications for Real Estate Valuation: A Review of Literature, in: 2nd International Conference on Real Estate Management and Valuation (ICREMV). pp. 120-124. https://doi.org/10.6084/m9.figshare.12094158.v1

[26] Munasinghe, L., Gunawardhana, T., 2017. Digital Disruption In Cyclical Consumer Services In Sri Lanka; Reference to Peer to Peer Accommodation driven by Online Booking Platforms, in: 10th International Research Conference "Changing Dynamics in the Global Environment: Challengers and Opportunities"; General Sir John Kotelawala Defense University. https://doi.org/10.6084/m9.figshare.12093306.v1 